\title{
Tijelo, identitet i tjelesne modifikacije
}

\author{
Mirjana Adamović \\ Institut za društvena istraživanja u Zagrebu \\ e-mail: mirjana@idi.hr
}

\section{Ana Maskalan \\ Institut za društvena istraživanja u Zagrebu e-mail:ana@idi.hr}

\begin{abstract}
SAŽETAK Članak se bavi odnosom tijela i osobnog identiteta te problematizira utjecaj strukturalnih faktora (kapitalizma i globalizacije) na pozicioniranje tijela u modernim društvima. Nalazimo da tijelo sve više postaje osobni projekt, predmet kreacije ali je istovremeno podložan unificirajućim i multikulturalnim tendencijama mijenjanja. Kreće se od pretpostavke kako globalna tržišta potiču standardizaciju potrošačkih navika i vrijednosti što se očituje i u načinima modifikacije tijela. Naglasak je stavljen na ekstenzivne metode modifikacije (estetska kirurgija) koji rezultiraju na dobnim, obiteljskim i rasno/etničkim distanciranjem.
\end{abstract}

Trendovi mijenjanja tjelesnog izgleda rukovode se izgledom tjelesnih ideala koji kroz produkte kulturnih industrija vrše globalni utjecaj. Tako su uz "standardizaciju" i "vesternizaciju" tjelesnog izgleda prisutni i drugi, nehomogeni tipovi "standardizacija" tijela kao i postupci namjerne "groteskizacije".

U radu se pokazuje kako se ekstenzivne modifikacije tijela ne mogu promatrati izvan matrice rodne moći. Kako je ovaj problem česta tema (post)feminističkih teorija tako ovdje, kroz to gledište i njegovu kritiku, analiziraju i problematiziraju ekstremne modifikacije tijela prisutne u radovima francuske umjetnice Orlan koji pokazuju potencijal prema subverziji patrijarhalnih očekivanja spram žena.

Ključne riječi: tijelo, identitet, globalizacija, žene, tjelesne modifikacije, estetska kirurgija.

\section{Uvod}

Cilj ovoga rada je objasniti ulogu tijela u izgradnji identiteta i utjecaje koje na osobni identitet a onda i tijelo kao važnu i vidljivu odrednicu toga identiteta imaju razvoj kapitalizma i prevladavajući globalizacijski procesi. Prihvatit ćemo tezu Anthony Giddensa prema kojoj sebstvo nije pasivan entitet u potpunosti determiniran 
vanjskim utjecajima te da u stvaranju osobnih identiteta individue pridonose i direktno unapređuju društvene fenomene koji su globalni u svojim implikacijama i konzekvencama. Osobni identitet shvaćamo kao proces kojim se produciraju i reproduciraju jedinstveni narativi o sebi (Giddens, 1991.:54); on je refleksivni projekt i objekt individualne odgovornosti. U središtu ovog rada je pojam tijela kao integralni dio osobnog identiteta čije (namjerne) promjene imaju značajan utjecaj na njegovo oblikovanje.

Utjecaj globalizacijskih procesa na vrste i značenja tjelesnih promjena je dvojak: prvo, unatoč dojmu o postojanju "beskrajnih" mogućnosti preoblikovanja tijela ovdje nastojimo pokazati kako postoje dominantni (zapadni) trendovi u prihvaćanju sličnih intervencija na ili u tijelo, čiji je krajnji rezultat naglašeno unificirajuće prirode po tjelesni izgled; i drugo globalizacijski procesi otvaraju vrata utjecaju nepoznatih i egzotičnih kultura na prakse odnošenja prema tijelu (kultivacija i estetika) koje bivaju prerađene i nanovo reinterpretirane.

Unatoč mnoštvu vrsta tjelesnih modifikacija u ovom je radu naglasak stavljen na one čiji je krajnji cilj estetske prirode. Lijepo tijelo u suvremenom se kapitalističkom društvu vezuje uz proklamirane vrijednosti mladosti, zdravlja, fizičke snage, izdržljivosti i erotičnosti. Lijepa su tijela ujedno produktivna tijela u kapitalističkom radnom procesu te su istovremeno objekti zavođenja moderne oglašivačke industrije u svrhu poticanja konzumacije. Medijski proklamirani tjelesni ideali bitno utječu na trendove estetskih tjelesnih promjena koje uključuju niz manje ili više zahtjevnih praksa od kojih su dijeta, vježbanje, kozmetika i kirurške intervencije postale zadnjih dva desetljeća izrazito popularne.

Od raznih vrsta tjelesnih promjena u ovom će radu veći naglasak biti stavljen na estetske kirurške promjene tijela, kao one koje imaju ulogu njegove estetizacije (onda i seksualizacije) a prema nekom od brojnih estetskih ideala. Estetskim se operacijama ostvaruju najradikalniji oblici promjena tijela koje rezultiraju različitim posljedicama, o čemu će u ovom radu također biti riječi.

Potencijal estetske kirurgije u promjeni osobnog identiteta prepoznale su mnoge žene, čija su tijela, povijesno gledano, predstavljala objekt nadzora, kontrole, prisile i manipulacije unutar patrijarhalne matrice moći. Posebno postfeministkinje naglašavaju važnost radikalnih tjelesnih modifikacija kao ženskog oblika prisvajanja moći nad vlastitim tijelom, vlastitim ženskim identitetom pa onda i vlastitom sudbinom. Rad završava kritikom kirurških promjene ženskog tijela kao emancipatorskog projekta (u svjetlu rada umjetnice Orlan) i globalnih, kapitalističkih i još uvijek premoćno patrijarhalnih obrazaca vezanih uz određivanje tjelesnih standar$\mathrm{da}^{1}$ koji negativno utječu na taj pokušaj emancipacije.

1 U suvremenim se društvima uz tijelo vežu pojmovi "ideala" i "standarda". Po definiciji ideal može imati tri značenja: "1. pojam zamišljen u najvećem savršenstvu da bi poslužio kao cilj kojem se teži; 2. savršeni stvarni primjer koji može poslužiti kao uzor u svojoj vrsti; 3. konačna težnja, željeno ostvarenje neke osobe ili društvene ambicije" (Anić et al., 2004.: 


\section{Tijelo i identitet}

Povijesno gledano, u središtu mnogih filozofskih i religijskih sistema koji su razmatrali bit čovjeka uspostavljen je hijerarhijski dualizam između čovjekovog duha i tijela pri čemu je duh imao primat nad tijelom te tako činio osnovu onoga po čemu je čovjek to što jest. Pojam identiteta zapadnog čovjeka uvelike je pod utjecajem platonovsko-kršćanske a onda i kartezijanske tradicije koje ga smještaju u binarne opozicije (duhovno/tjelesno, nepromjenjivo/promjenjivo), aktualizirajući pritom hijerarhijske odnose između pretpostavljenih konstitutivnih elemenata identitetskog konstrukta.

Dok antičko poimanje tijela sjedinjuje fizičke s moralnim i intelektualnim kvalitetama $^{2}$, rana je filozofija marginalizirala njegovu važnost određujući posjedovanje uma temeljnim i najvrednijim obilježjem čovjeka za čiju je sreću zaslužna besmrtna duša a ne prolazna tjelesna ljuštura. U kršćanskoj je tradiciji tijelo smatrano nepostojanim, pasivnim, grešnim i manjkavim, preprekom i mučnim teretom na putu ljudskog duha prema božanskom. Uspostavljajući hijerarhijski odnos duha i tijela slična se logika vrednovanja primjenjivala i nad ostalim obilježjima individua i kolektiviteta što se očitovalo i očituje u drugim prirodnim (onima koje se odnose na tijelo i njegove oznake) ili konstruiranim (religijskim, političkim, itd.) stratifikacijama.

Od druge polovice 19. stoljeća pojavljuje se povećani interes za tijelo što se ogleda u zanimanju za tijelo u različitim disciplinama, prvenstveno antropologiji. Osobito je postala popularna antropometrija odnosno mjerenje, uspoređivanje i klasifikacija tijela i kranijalnih karakteristika (Friedman, 2005.). Taj su interes potaknula u širem kontekstu dva procesa: prvo, uvećan interes za neeuropska društva i briga za loše uvjete radničke klase u demografskom (visoki mortalitet), zdravstvenom (podložnost oboljenjima) ali i socijalnom smislu (sklonost alkoholizmu) (Varga, 2005.); i drugo, susret s novim kulturama i nagim, ukrašenim, bojanim ili ožiljkovanim tijelima izazvali su čuđenje čovjeka Zapada ali i osnaživali njegovu svijest o superiornosti bijele rase u fizičkom smislu te usvojenim "kvalitetnijim" kulturnim navikama spram tijela (hranjenje, higijena, držanje tijela, geste, odnos prema spolnosti itd.).

163). Dok se prvom definicijom sugerira neostvarivost ideala, druge dvije dopuštaju njegovu mogućnost ostvarenja. Standard je pak "1. propis kojim se određuje kakvoća, veličina i druge osobine proizvoda; 2. kriterij, obrazac za usporedbu" (2004.:129).

Moderna upotreba riječi ideal, kada se koristi u kontekstu rasprava o tijelu i ljepoti, sugerira njegovu drugu i treću definiciju. Tako definirani ideal za sobom povlače određenje jasnih tjelesnih standarda. Smatramo kako određenje ideala (uvjetno) ostvarivim pod pretpostavkom zadovoljenja određenih tjelesnih standarda ima ideološku funkciju, koju ćemo obrazložiti u daljnjem tekstu.

$\mathbf{2}$ Antički ideal čovjeka opisivao je biće fizičke i moralne ljepote označenog pojmom "kalokagathia" (kalos=lijepo i agathos=dobro). 
Uspoređivanje tjelesnih karakteristika u povijesnom je slijedu također postalo jedan od temelja rasističkih i fašističkih ideja koje u osnovi počivaju na tradicionalnoj pretpostavci kako tijelo zrcali umne i duševne karakteristike ljudi od kuda je izveden "dokaz" "ne-ljudskog" ili "manje-ljudskog" statusa nepoželjnih rasnih i etničkih društvenih skupina. Michelle Hirschhorn (1996.) tvrdi da je u našoj kulturi lice najznačajnija karakteristika ljudske identifikacije pa ono ima privilegirani status u odnosu na ostatak tijela. Hirschorn se tako nadovezuje na rad Deleuzea i Guattarija (2004.) koji su ustvrdili kako rasizam svoje temelje pronalazi u uočenim odstupanjima od određenog facijalnog standarda. Standardno lice, prema njihovu mišljenju, nije ono bijelog muškaraca - ono jest bijeli muškarac. Hirschhorn proširuje njihove stavove razmatranjem seksizma pa zaključuje kako rasizam i seksizam funkcioniraju određivanjem stupnjeva devijacije u odnosu na lice bijelog muškarca. I ne samo rasa ili spol već i etnicitet pretpostavlja niz, na licu očitovanih značajki. Lice je poprište odnosa moći, mjesto u kojem se ukrštavaju razna značenja i na osnovu kojeg se odvijaju ukalupljivanja prije nego što se izgovori i jedna jedina riječ. Zato Deleuze i Guattari zaključuju kako je lice političko. Ono je nositelj oznaka moći ili njezinog nedostatka sa svim svojim konzekvencama. Nije stoga slučajno da su na popularnost kirurških estetskih intervencija utjecali i židovska i crnačka lica (svjetlije puti) čiji su vlasnici operacijama pokušali izbjeći jedno ili više rasnih tjelesnih obilježja (Gilman, 2001.).

Iako je tradicija izražena u hijerarhijskim dualizmima utjecala na podcjenjivački odnos prema tijelu što se protezalo kroz religijsku, umjetničku, znanstvenu i svekoliku ljudsku djelatnost, pojedini su moderni mislioci formirali bitno drukčije stavove o tijelu od onih koji ga svode na tamnicu duha ili stan duše.

Protu-kartezijanski stav Merleau-Pontya temeljio se na ideji kako "čovjek jest tijelo" te kako su sva naša osjetila izvori povezanosti sa svijetom oko nas. Tijelo je prema njemu jedan od prvih temelja identiteta, ono je "vozilo bitka u svijetu, a imati tijelo, to za živo biće znači spojiti se s određenom sredinom, stopiti se s izvjesnim projektima i u njima se neprekidno angažirati” (1990::108). U procesu formiranja identiteta, tijelo i njegovo okruženje su u neprestanom procesu međusobne interakcije. Tijelo, prema Merleau-Pontyiu, nije objekt, nego je prije u srži određenja subjektivnosti i svjesnosti, ono je aktivno sredstvo bivanja u svijetu.

Elementi inovativnosti bitni za teoriju tijela nađeni su, između ostalih, i u djelima Durkheima, Goffmana, Foucaulta, Giddensa i Schillinga koji su ustvrdili vezu između tjelesnih svojstava i kreacije društvenog života. Analitička konvergencija u djelima potonjih autora pokazala je kako je tijelo sredstvo društvenog pozicioniranja i orijentacije. Društvo se upisuje u tijela stimulacijom i razvijanjem određenih potreba, navika i aktivnosti. Ipak, tjelesna bića nisu u potpunosti određena društvom jer subjekti posjeduju razlikovne i kreativne kapacitete koji proizlaze iz njihove individualne svjesnosti.

Durkheimovo (2008.) je istraživanje istaknulo elemente simboličkog karaktera kulturalnog poretka i tijela kao mjesta njihove saturacije. U pokušajima upravljanja 
tjelesnom produktivnom moći ljudi su koristili tjelesni simbolizam koji je pomagao kreiranju solidarnosti i eliminaciji onih koji nisu pripadali zajedničkoj kulturi. Durkheim je opisao simboličko shvaćanje ljudskoga tijela pokazujući kako su različita vjerovanja povezana sa shvaćanjem svetoga u domorodačkim društvima. Tvrdio je da društveni život počiva na vrijednosnom sustavu i moralnim načelima koji oblikuju kolektivnu svijest. U pokušaju razrješenja dualizma duha i tijela odnosno načina na koji ljudi spoznaju svijet oko sebe on uviđa značaj društvenog jer su logika, koncepti, moral i vjerovanja produkti kolektiviteta.

Na naslijeđu Durkheimovih ideja Erving Goffman (1956.) naglašava važnost dojma u kontekstu odnosa među individuama. Kvalificirajući odnose među ljudima dramaturškim modelom, Goffman smatra kako informacije o individuama pomažu "definiranje situacije" a drugima omogućuju znanje o tome što od nekoga mogu očekivati. Predodžba o sebi jedna je od takvih informacija zajedno s podacima o spolu, rodu, društveno-ekonomskom statusu, kompetencijama i ostalim bitnim izvorima. Individue izražavaju sebe a ponekad i kalkuliraju o tome što bi druge trebalo impresionirati odnosno trude se ostaviti dojam na osnovu kojeg bi ih drugi vidjeli u skladu s njihovom predodžbom o sebi. U svakodnevnom životu postoji jasno razumijevanje o tome koliko su prve impresije i inicijalne interakcije bitne.

Upravo je "tijelo kao projekt" jedna od značajnijih sintagmi kojom se opisuju načini na koje se individue odnose prema vlastitom tijelu. Tu sintagmu Giddens (2000.) koristi kako bi sugerirao odbacivanje tradicije popraćeno ontološkom nesigurnošću i refleksivnom brigom za identitet i tijelo. Tijelo kao projekt veza je između identiteta i vanjskog tjelesnog sebstva. To je vanjsko tjelesno sebstvo postalo, uslijed tehničkog razvoja kozmetičke i transplantacijske kirurgije, genetike i kiber-tehnologije, poprištem individualnog izbora i upliva društvene tehnologije. Igranje uloga omogućuje programiranje izgleda i eksperimentalnih vizija sebstva te na prvi pogled otvara nebrojene mogućnosti eksperimentiranja i mijenjanja do tada nepromjenjivog: "Osobni život postao je otvoreni projekt, koji stvara nove zahtjeve" a "naše međusobno postojanje potpuno se promijenilo uključujući nas u "svakodnevne društvene eksperimente" - tvrdi Giddens (2000.:17). Ono što se primjenjuje na jastvo, smatra Giddens, primjenjuje se i na tijelo koje postaje "natopljeno misaonošću".

Schilling (2005.) tvrdi kako je tijelo istovremeno izvor, mjesto i sredstvo čime sugerira povezanost različitih koncepata koji se odnose na generativne karakteristike tijela, njegovu društvenu recepciju i njegove kapacitete usmjerene ka interakciji individua, grupa i strukturalnih oblika društva. Važnost utjecaja društva ne marginalizira značaj utjelovljenog subjekta jer se ljudi konfrontiraju s danim strukturama koje postoje znatno ranije nego što je započela njihova aktivnost. Tijelo, prema tome, nema samo svoje granice i metaboličku mrežu nego i kapacitete djelovanja. Razmatranje tijela na način na koji to sugerira Schilling podrazumijeva analitiku brojnih varijabli, pa je važno, kaže on, odrediti čija su tijela najproduktivnija ili pak ograničena društvenim utjecajem i u kojoj vremenskoj točci - što je osobito bitno u razmatranju razloga transformacija tijela i utjecaja kulture na njih. 
Možemo zaključiti da se promjena u stupnju značaja koja se dodjeljuje tijelu u procesu kreiranja identiteta dogodila uslijed procesa individualizacije u modernim i postmodernim društvima i odbacivanja tradicionalnih društvenih veza (Bauman, 2000.) iz čega je proizašla potreba individua za izražavanjem svojih stavova i perspektiva. Izgradnja sebstva u postmodernitetu je odijeljena od kolektivnih fizičkih rituala i koncentrirana na individualne činove. Suvremena društva naglašavaju važnost tijela, otvarajući mnoge, tehnički posredovane, mogućnosti individualne intervencije u tjelesni izgled.

Unatoč potencijalno emancipatorskim idejama vezanima uz koncept "tijela kao osobnog projekta" u daljnjoj ćemo analizi pokazati u kojoj mjeri strukturalni faktori utječu na tjelesne modifikacije te mnogih načina na koje su individue stavljene pred izbore i izazove. Pritom je nemoguće zaobići Foucaultov (1978.-1988.; 1994.) opis društvenog miljea u kojem se nad tijelom provode razni postupci regulacije, liječenja, kažnjavanja i slično. Reguliranja i discipliniranja tijela se ne provode samo prisilom nego i ustanovljavanjem ideala i normi u pogledu seksualnosti, zdravlja i poželjnosti tijela te optimiziranja tjelesnih mogućnosti.

Također, valja napomenuti kako koncept "tijela kao projekta" nije lišen dominantnog obrasca utjecaja bijele rase pa on često disperzira antisemitske i rasističke vrijednosti (Featherstone, 1999.) i marginalizira emocionalna iskustava i ekspresije (Schilling, 2005.). Na tragu ideja Deleuzea i Guattari (2004.) nadalje ćemo pokazati kako ne samo lice nego i izgled tijela postaju nositelji oznaka moći. Koje su to strukturalne odrednice koje utječu na mijenjanje tijela pokazat ćemo u sljedećem poglavlju.

\section{Kapitalizam, globalizacija i tijelo}

Smatramo kako su promjene u kapitalističkim društvima te razvoj konzumerističke kulture značajno utjecale na pozicioniranje tijela u centar oblikovanja ljudskog osjećaja identiteta. U tijelu je pronađeno sredstvo za pokretanje konzumacije te ono, da bi što uspješnije obavljalo tu funkciju, postaje podložno kontroli i manipulaciji, bivajući i samo oblikovano prema komercijalnim mjerilima. Tijela se u postmodernim društvima iskazuju i kao forma fizičkog kapitala (Bourdieu, 1978.), koja se, oslobođena kršćanskih konotacija "spremišta grijeha”, može konvertirati u ekonomski kapital.

Schilling (2005.) naglašava važnost analize različitih društvenih područja koncentriranih na upotrebu, preoblikovanje i izlaganje tijela u radnom procesu, sportu, muzici, tehnologiji, odnosno društvu općenito. Pod utjecajem Marxove ${ }^{3}$ analize vrijed-

\footnotetext{
3 Marx u djelu Kapital (1958.: 131) razmatra radnu snagu ili radnu sposobnost kroz cjelokupne fizičke i duhovne sposobnosti koje "postoje u tjelesnoj, živoj ličnosti čovjekovoj, i koje on stavlja u pokret kad god proizvodi upotrebne vrijednosti ma koje vrste". Vrijednost radne snage, smatra Marx, određuje se kao i vrijednosti drugih roba, radnim vremenom potreb-
} 
nosti radne snage on smatra kako rad ima temeljni udio u određenju individualnog identiteta što zagovara i Iris Marion Young (2005a) kada kaže da se identitet čovjeka u suvremenim društvima premoćno određuje preko zanimanja. Industrijalizacija je povisila radno vrijeme kao i potrebe poslodavaca u složenom procesu tržišnog konkuriranja pa u kontekstu tih činjenica ljudi pristupaju tijelu kroz različite norme. Fordizam i postfordizam kao i kulturne norme koje su im prethodile, utjecali su na to da je radno tijelo postalo "organizacija" inputa i outputa, potreba i prioriteta. Opsjednutost fizičkim izgledom postala je protuteža dugotrajnom i iscrpljujućem radnom angažmanu. Analiza radnih tijela, onih kojima osobe prezentiraju sebe u svakodnevnom životu, pokazuje važnost "impresijskog menadžmenta" "upravljanja dojmom o sebi" kojim ljudi nastoje steći i održati svoj status u društvu čime se pokazuje koliko su plaćeni rad i rad na tijelu međusobno povezani ${ }^{4}$.

Naglašeni interes za tijelo Urlich Beck (1992.) objašnjava suvremenošću kao vremenom nesigurnosti i rizika zbog čega se individue okreću ka vlastitom tijelu kao mjestu kontrole i izvorištu izgradnje identiteta. U političkoj ekonomiji nesigurnosti, kako ju on naziva, u kojoj su stabilni poslovi rijetki i postoji konstantna nesigurnost, važnost zadržavanja radnog mjesta postaje centralni životni prioritet. Nadalje, ako se na poslu izgara, onda starost više nije resurs koji donosi iskustvo i lakše obavljanje poslova nego postaje smetnja i sinonim nekompetencije. Mladost i kultivacija mršavog tijela (lišenog neproduktivnih viškova) obećava lakše obavljanje paralelnih zadataka, veću samokontrolu i motivaciju. Istovremeno se prirodne tjelesne oznake tijela, u prvom redu znakovi starenja, nastoje prikriti ili poništiti. Negacija prirodno determiniranog tijela obilježenog neumitnim propadanjem, "kvarenjem" podrazumijeva mogućnost da ono postane predmet naizgled beskrajnih (pre)oblikovanja. Više nego ikada prije, poželjan tjelesni izgled postaje vezan uz namjeru individue da uveća svoju socijalnu mobilnost.

Konzumacija objekata, vitalna za funkcioniranje kapitalizma, ne propagira individualnu odgovornost nego stvara privid individualne aktivnosti i spontanosti, što

nim za proizvodnju i reprodukciju "ovog naročitog artikla". U skladu s vremenom u kojem je pisao Kapital, Marx je smatrao kako veće trošenje radne snage (mišića, živaca, mozga itd.) uključuje i veća primanja. Suma namirnica koju je trošio radnik trebala je biti dovoljna da održi radnu individuu u normalnom životu. Osim prirodnih, nužnih potreba Marx je smatrao kako su potrebe i način njihova zadovoljavanja historijski uvjetovane pa "određenje vrijednosti radne snage sadrži izvjestan historijski i moralni element" (1958.:134). On je primijetio kako istrošenost i smrt odvlače radnu snagu s tržišta pa suma životnih namirnica mora uključivati i životne namirnice i obrazovanje zamjenika, tj. radničke djece. U objašnjenju prirode procesa rada kao "društvenog oblika" dolazi do procesa čovjeka i prirode u kojem čovjek kao prirodna sila istupa prema prirodnoj materiji, "ali ono što unaprijed odvaja i najgoreg graditelja od najbolje pčele jeste da je on svoju komoru izgradio u glavi prije no što će je izgraditi u vosku" (ibid., str. 139).

4 Danas su mnoga medijska i uslužna zanimanja povezana s fizičkim izgledom. Iako se zapošljavanje u tim zanimanjima nikada formalno ne dovodi u vezu s tjelesnim izgledom, postoje neformalna pravila o tome kako bi osobe, koje rade te poslove, trebale izgledati. 
pak, u osnovi, podržava kapitalističku potrebu za potrošnjom. Nadovezujući se na ovo, teorija racionalnog izbora postavlja pitanje je li tijelo subsistem djelovanja, tj. je li ono samo instrument akcije u nizu ustanovljavanja i ostvarivanja ciljeva subjekata čime je ono poistovjećeno s životnim projektom jednako važnim kao i osiguranje materijalnih uvjeta života.

Individualne su se mogućnosti raspolaganja tijelom u suvremenosti uvećale, ali se istovremeno ojačala i regulacija tijela kroz mnoge suptilne forme - simbole, proizvodnju potreba, navika i želja, cirkulaciju slika te stvaranja ideja o tome kako bi tijela trebala izgledati. Simboličke su vrijednosti konzumerizma u suvremenim društvima, kako tvrdi Baudrillard (2001.), preko institucionalnih regulacija, značajan element u kontroli ponašanja.

S obzirom da je seksualnost središnja tema "estetskih tehnologija", publiciteta, pornografije, biozahvata i antropoloških refleksija (Kalanj, 2004.:208), klijenti/ce estetskih modifikacija se nerijetko odlučuju na one vrste zahvata koje reklamiraju seksualizirani tjelesni ideali čija tijela uz ukupnu seksualnu atraktivnost posjeduju i naglašeno erotizirane pojedine dijelove poput usta, grudi, stražnjice itd. Razlozi takvih investicija u svoj izgled nalaze se u individualnim očekivanjima da će ona donijeti neku materijalnu odnosno društvenu korist pa se pitanja tijela i tjelesnog izgleda raspravljaju i unutar odrednica "erotskog kapitala" (Green, 2008.).

Tijelo kao erotski kapital omogućeno je promijenjenim društvenim odnosom prema seksualnosti odnosno onime što je Foucault prepoznao kao javnu opčinjenost seksom. Time se ono što je vezano uz spolnost pretvara u trgovačku robu. "Spolne slike pojavljuju se gotovo posvuda na tržištu kao neka vrsta divovske prodajne varke. Prevlast spolnosti mogla bi se protumačiti kao (s)kretanje iz kapitalističkog poretka, koji ovisi o radnoj snazi, disciplini i samoodricanju, prema poretku koji potiče potrošački mentalitet i prema tome hedonizam" (Giddens, 2000.:230). Riječ je, kako kaže Baudrillard (2001.), o prividno savršenim i banalnim slikama koje estetiziraju svakodnevni život.

Time je uspostavljena sprega između kapitalizma te instrumentalnog shvaćanja ljepote, mladosti, zdravlja i bolesti. Estetske se mane i nedostatnosti obavijaju aureolom nepoželjnosti i straha, a ljudima nameće lažni osjećaj da kupujući proizvode koji ih uklanjaju zapravo brinu o "zdravlju".

Tijela sportaša, filmskih zvijezda, popularnih muzičara i modnih ikona imaju veliki utjecaj na procjenu važnosti tjelesnog izgleda u svakodnevnom životu. Dakako, ta su tijela, sve češće, i sama predmetom čestih kirurških i ostalih kozmetičkih preobrazbi a njihove slike do šire publike najčešće dolaze dodatno izmijenjene digitalnim tehnikama obrade fotografija i snimaka. U tom smislu se oni mogu smatrati simulacrama, nepostojećim izvorima žudnje i frustracije koju je donekle moguće utažiti samo kupovinom pratećih proizvoda ili investicijom u sličan tjelesni izgled. 
Globalizacijski procesi su promijenili svakodnevni život, potaknuvši različite procese redefiniranja rodnih uloga, spolnosti, obiteljskih i ostalih odnosa s drugima, na svim razinama života. Sraz telekomunikacija i kapitalizma obilježen je, prema Danny Quahu (2003.), razvojem bestežinske ekonomije koja svoju zaradu ne crpi na osnovu vrijednosti materijalnih proizvoda, već na osnovu vrijednosti informacija.

Razvojem telekomunikacijske tehnologije omogućena je kompresija prostora i vremena koja je utjecala (Giddens, 2007.:53) na susret kultura i razmjenjivanje informacija ne samo verbalnog nego i vizualnog tipa pa stoga globalizacija ima u kulturi očite vizualne reperkusije. Napredne su tehnologije usmjerene u velikoj mjeri prema ljudskom tijelu - od intervencija u ljudsku reprodukciju, dijagnostike i liječenja pa do estetskih promjena. Jedan od načina na koje tijelo u postmodernitetu postaje društveno kulturalni konstrukt jest onaj vezan uz upotrebu tehničkih sredstava koja služe transcendiranju vlastitih ograničenja.

U postmodernitetu se, zahvaljujući komunikacijskoj tehnologiji i virtualnoj realnosti, individua "oslobađa prirodnog tijela" jer uspostavlja odnose bez fizičke prisutnosti i prezentira sebe na način na koji to pošiljatelj informacija želi. Virtualno tijelo može imati različite oblike - ono, najvažnije, nije izloženo ni starosti, ni bolesti, ni ružnoći (naravno, ukoliko njihov vlasnik/ca ne odluči drukčije).

Mediji su okosnica one vrste kapitalizma koja svoj izvor zarade nalazi u informacijama vizualnog tipa. Radio i televizijske emisije, video spotovi, moda, filmovi itd., dijele elemente globalnih trendova i utječu na disperziju kulturalnih kodova o tome kako tijela "trebaju i mogu izgledati". Moćne industrije (dijetetska ${ }^{5}$, kozmetička, farmaceutska, industrija estetske kirurgije ${ }^{6}$ ) često i same stvaraju umjetne potrebe te imaju bitnu ulogu u proizvodnji "masovne tjeskobe" kod potrošača/ potrošačica.

U društvu u kojem su prosječnost i neuglednost sve više tretirane kao bolesti, individue često ne doživljavaju tjelesne modifikacije kao nešto u potpunosti ovisno o vlastitoj dobroj volji već kao svoju odgovornost i obavezu. Na to se nadovezuje uvjerenje kako je postizanje idealnog i "vanvremenskog" tijela dostižan cilj za koji su potrebni samo odgovornost prema sebi, disciplina, volja i trud. Pritom se financijska i genetska ograničenja (namjerno) previđaju.

5 Dijeta se pojavljuje s razvojem znanosti o ispravnom hranjenju i povezana je s "administrativnom moći u Foucaultovom smislu riječi" ali ona također "postavlja odgovornost za razvitak i izgled tijela izravno u ruke njegova posjednika". Ono što čovjek jede izraz je odabira njegovog životnog stila "jer dijeta povezuje fizički izgled, samosvojnost i spolnost u kontekstu društvenih promjena s kojima se pojedinac hvata u koštac" (Giddens, 2000.: 46-47).

6 Nazvati ove industrije "moćnima" nije nimalo pretjerano budući je njihova godišnja zarada, o čemu izvještava Naomi Wolf, golema. Konkretno, zarada dijetetske industrije se u SAD-u kreće oko vrtoglavih $33 \mathrm{mlrd}$. \$ godišnje, kozmetičke oko $20 \mathrm{mlrd}$.\$, pornografske 7 mlrd. \$, a industrije plastične kirurgije 300 milijuna \$ (2008.: 28). 
Medijski ideali se pojavljuju kao referentne točke prema kojima se ljudi pozicioniraju iako se pri tome to pozicioniranje ne ostvaruje s obzirom na stvarne ljude i njihova stvarna tijela već, kao što je već rečeno, s obzirom na iluzije, fantazme, nepostojeće a onda i nedosezive ideale. Ti se ideali nastoje dosegnuti raznim oblicima tjelesnih modifikacija od kojih u središte našeg interesa ulaze kirurške intervencije.

Danas svjedočimo sve većem porastu ${ }^{7}$ intervencija u tijelo pri čemu smo zapazili određene trendove. Postoje najmanje dva dominantna trenda estetskih promjena tijela, ovisno o tome jesu li usmjerena prema njihovoj "standardizaciji" ili "groteskizaciji". Standardizacija tijela podrazumijeva kirurške intervencije u tijelo s namjerom dosezanja određenog (društveno zadanog) tjelesnog standarda koji podrazumijeva jednu ili više popularnih tjelesnih proporcija ili normi ${ }^{8}$. Globalna se pripadnost premoćno ostvaruje prihvaćanjem zapadnjačkih tjelesnih standarda te kirurških intervencija u tijela čija je svrha njihova "vesternizacija". "Vesternizacija" tijela nije homogenog karaktera jer ne postoji jedan već brojni ideali lijepoga tijela (Jung, Forbes, 2007.; Mumford, Choudry, 2000., Ishiguro, 2009.). Za razliku od "vesternizacije" tijela, na Dalekom se Istoku uočavaju trendovi stvaranja "panazijskih" tjelesnih oznaka što na izvjestan način sugerira relativno čvrstu rasnu identifikaciju koja, međutim, odstupa od nekih tipičnih rasnih karakteristika u pojedinih etniciteta. Radi se, naime, o pokušaju pripadnika i pripadnica azijskih naroda da estetskim korekcijama onemoguće izravnu identifikaciju sa bilo kojom etničkom zajednicom unutar azijske populacije pa je na djelu svojevrsni estetski eklekticizam?

7 Statistički podaci Američkog društva za estetsku plastičnu kirurgiju pokazuju da je u SADu 2008. godine izvedeno 10,2 milijuna estetskih kirurških i ne-kirurških postupaka što je povećanje od 162\% u odnosu na 1997. godinu, kada su rađene prve statističke analize. Najčešći suvremeni kirurški postupci su povećavanje grudi, liposukcija, operacija vjeđa, rinoplastika i abdominoplastika. Oko 98\% svih kirurških estetskih tretmana izvodi se na ženskom tijelu pri čemu su se u 2008. godini uglavnom povećavale grudi $(355,671)$ a potom slijedi uklanjanje masnih naslaga (309,692 postupaka). Po prvi puta je nakon 12 godina, prvo mjesto ispred liposukcije zauzelo kirurško povećanje grudi što stručnjaci objašnjavaju promjenama u modnoj industriji koja sve više naglašava ženske grudi otkrivajući njihove dekoltee. Još jedan razlog za to može se pronaći u medijima i popularnoj kulturi ali i pornografiji koje posljednjih godina gravitiraju prema oblijem izgledu žena zbog čega "višak" masnih naslaga (dakako, na "pravim" mjestima) ne mora nužno voditi u njihovo odstranjivanje.

Samo je 8\% svih kirurških estetskih zahvata, 2008. godine, izvršeno na muškim tijelima pri čemu su najčešće od odabirane liposukcija (31,453 postupaka), rinoplastika, operacija vjeđa, smanjenje grudi i transplantacija kose. (Izvor: Američko društvo za estetsku kirurgiju, 2010.)

$\mathbf{8}$ Često spominjan i istican kanon proporcija predstavlja Vitruvijski čovjek, odnosno tijelo idealnih proporcija ovjekovječeno crtežom Leonarda da Vincija.

9 Ovome valja dodati želju mnogih pripadnika/ca azijskih naroda da izgledaju "zapadnjačkije" zbog čega se podvrgavaju tzv. korekcijama nogu. Iza sintagme "korekcije nogu" skrivaju se izrazito bolni i dugotrajni postupci produljivanja kostiju potkoljenica kako bi pacijenti/ ice "narasli" za nekoliko centimetara. 
Osim popularnih postupaka "standardizacije" prisutne su i pojave "groteskizacije" tijela pod kojima mislimo na kirurške intervencije u tijelo s namjerom radikalnih van-standardnih mijenjanja, povećanja ili isticanja pojedinih dijelova tijela. Grotesknima, dakle, određujemo namjerno izobličena tijela a ne ona koja su nastala uslijed nenamjernih i katastrofalnih posljedica kirurških zahvata. Razloge tjelesne "groteskizacije" nalazimo kako u pristupima tijelu kao kreativnom i umjetničkom projektu tako i u pristupima tijelu kao potencijalnom izvoru zarade (i popularnosti) što svoje značajno mjesto nalazi u suvremenoj pop-kulturi šoka, voajerizma, ekshibicionizma i pornografije. "Groteskizacija" tijela osobito je zamjetna kod intervencija u žensko tijelo. Groteskizirana ženska tijela dovodimo u prvom redu (iako ne i isključivo) u vezu s utjecajem pornografske industrije na žensku percepciju vlastitog tijela i njegove poželjnosti, o čemu će više biti riječi u sljedećem poglavlju.

Manipuliranje dojmom o sebi posredstvom tehnike (prvenstveno estetske kirurgije) ima posljedice koje smo nazvali distanciranjem ${ }^{10}$. To se distanciranje očituje na tri razine: dobnoj, obiteljskoj i etničko/rasnoj.

Prvo, manipulativne tehnike kirurškog pomlađivanja udaljuju individuu od njezine dobne skupine. Drugi oblik distanciranja događa se kada novi fizički izgled odudara od izgleda obitelji, predaka i potomaka ${ }^{11}$. Treće, upotreba kirurških postupaka ima utjecaj na distanciranje od pripadnika vlastitih etničkih ili rasnih zajednica. U ovom potonjem primjeru prisutna je barem jedna od dvije prethodno navedene razine jer dolazi do distanciranja ne samo od izgleda rasno/etničke zajednice sa njezinim prepoznatljivim oznakama (boja kože, oblik očiju i nosa, veličina usta, stas, rast itd.) već i do distanciranja od članova vlastite obitelji, predaka i potomaka. Kakve to ima reperkusije na društvenost tek bi trebalo istražiti.

Globalizacijski procesi su isto tako rezultirali i populariziranjem rasno prepoznatljivih oznaka tijela nedominantnih kultura. Taj se proces u teoriji pripisuje promjeni paradigme od kulturnog imperijalizma prema interesu za i utjecaju Drugih (Ishiguro, 2009.:98). To pokazuje da su globalizacijski procesi istovremeno i multikulturalni te su reaktivni odgovor na drugačiju artikulaciju suvremenih društava čiji drugošću određeni pripadnici (etnički i spolno drugačiji, kulturalno ekscentrični), traže ravnopravnost unutar političke zajednice (Paić, 2005.). U tom se kontekstu i konstrukcija tijela danas rukovodi elementima koji potječu iz različitih kulturnih izvora (Green, 2008.).

Dakle, unatoč postojanju dominantnih trendova unutar estetske kirurgije najčešce usmjerenih ka distanciranju individua od "nepoželjnih" tjelesnih osobina rasnih ili

10 Ovdje koristimo pojam distanciranja u kontekstu tjelesnog izgleda čijom se promjenom osobe svjesno ili nesvjesno tjelesno distanciraju od onih kojima su dotada bili slični. Distanciranje se može shvatiti i kao namjerno odustajanje od društvenih interakcija sa sebi (rasno, etnički, dobno) sličnima u užem i širem smislu. Međutim, imamo premalo podataka o osobama koje su izvršile estetske korekcije da bi mogli šire zaključivati.

11 Svi na svojim licima i tijelima baštinimo genetski materijal prethodnih i prenosimo ga u naslijeđe budućim generacijama. 
etničkih kolektiviteta, u suvremenom se društvu zapaža jačanje etničke i rasne svijesti o kojoj se vodi računa i prilikom kirurških zahvata u tijelo. Mnogi pacijenti/ice prilikom odabira estetskog kirurga/inje insistiraju na pripadniku/ci njihove rasne ili etničke skupine koji/a će prilikom estetskih zahvata pokazati razumijevanje ili "veći senzibilitet" za poštivanje rasnih i etničkih oznaka.

\section{4. Žensko tijelo između pokornosti i subverzije}

Analiza ženskog tijela unutar feminističke teorije ima također svoj plodni historijat s obzirom na to da su žene, povijesno gledano, identificirane s tijelom a iz njihovih je tjelesnih karakteristika patrijarhalna kultura izvodila moralne i karakterne osobine; slabost, pasivnost i podložnost nagonima (Beauvoir, 1982.).

Tijelo i njegove funkcije ženama su predstavljale, gledano u društvenom kontekstu, koliko izvor preokupacije, toliko i smetnju (menstrualni ciklusi, hormonske mijene, trudnoća, tjelesna nejakost itd.) u obavljanju određenih poslova, odnosno prilikom društvenih interakcija. Može se reći kako je žensko tijelo upleteno u patrijarhalnu mrežu moći bilo temelj društvene diskriminacije žena te je determiniralo njihove životne šanse.

Ženska određenost tijelom imala je dvojaki karakter: patrijarhalna je kultura, s jedne strane, žensko (lijepo) tijelo obožavala kao jednu od najvrjednijih osobina ženskog rodnog identiteta, a sa druge je strane, to isto tijelo i sve njegove funkcije smatrala smetnjom ženskom sudjelovanju u donošenju odluka u javnome, političkom životu (Pateman, 2000.). Ženski je rodni identitet i danas još uvijek u prvom redu obilježen tjelesnim reproduktivnim i estetskim karakteristikama (Touraine, 2006.).

Kapitalizam je u ženskim tijelima prepoznao veliki potencijal. Ženska tijela u kapitalističkom kontekstu imaju dvije osnovne uloge. Prva, (lijepa) ženska tijela su objekt zavođenja moderne oglašivačke industrije, poticatelj konzumacije i muškog užitka (pornografska industrija). Ona pritom egzistiraju kao ideali od kojih žene ne uče samo kako trebaju izgledati već i kako se trebaju ponašati, ona su medij poučavanja ispravne ženskosti. Erving Goffman (1976.) je svojom analizom ženskih i muških modela u modnoj industriji pokazao kako tjelesni ideali imaju značajnu ulogu u prenošenju normativnih ideja o muškosti i ženskosti te su rezultatom ritualiziranih i fetišiziranih kulturalnih izvedbi. Druga, s prvom značajno povezana, uloga ženskog tijela u kapitalizmu odnosi se na njegovu sposobnost konzumacije dobara. Industrija je pronašla mnoštvo načina kapitalizacije ženske određenosti tjelesnošću tako što je ženama ponudila proizvode za ulaganje u tu istu tjelesnost ali i tako što ih je obvezala na njihovo korištenje.

Upravo je preokupacija tjelesnim i njegovim negativnim nasljeđem bio jedan od ključnih interesa feministica drugoga vala koje su u cilju izjednačavanja s muškarcima pristupile "napadom na tijelo", suprotstavljajući se patrijarhalnoj perspektivi. Transcendiranjem tijela nastojalo se uvjeriti patrijarhalnu, mušku kulturu kako može i treba ući u dijalog sa ženama. 
Radikalne feminističke teoretičarke Andrea Dworkin i Catherine MacKinnon (Pitts, 2003.) odredile su ženske tjelesne modifikacije vanjskim izrazom internalizacije patrijarhalne mržnje prema ženskom tijelu. U kontekstu borbe za prava žena, feministice drugoga vala kritizirale su prikazivanje žena u pornografskim sadržajima kao tjelesno pasivnih i submisivnih za razliku od potencirane muške agresivnosti.

Istražujući tijelo kao društveno-kulturni artefakt Elizabeth Grosz (1995.) ustvrdila je kako treba pročistiti i promijeniti tradicionalni pojam tjelesnosti koji je uvijek smještan u različite opozicije (um/tijelo, vanjsko/unutarnje, iskustvo/društveni kontekst, subjekt/objekt, sebstvo/Drugi i, najznačajnije, muško/žensko). Vrijednost spolnoga tijela je velika jer mu društvo daje takvo značenje. Grosz smatra kako je spolna razlika kroz mnoge (pedagoške, zakonske, medicinske, ekonomske itd.) prakse imala za posljedicu specifičan odnos prema pojedinim dijelovima ženskog tijela (spolnim organima, sekundarnim spolnim karakteristikama itd.). Ona smatra kako imati žensko ili muško tijelo nije isto te da to ima utjecaj na način psihičkog doživljavanja sebstva ${ }^{12}$.

U analizi tjelesnih politika ona uočava nekoliko problema. Prvo, uviđa postojanje maskulinističke orijentacije politike prema tijelu. Falocentristička politika tijela duboko se oslanja na fundamentalnu opoziciju prirode i kulture. Drugo, pod tijelom se kao i pod prirodom misli na pasivnu materiju koju (muška i patrijarhalna) kultura treba transformirati ili kultivirati. Analogiju Grosz nalazi u preuzimanju kontrole kulture nad ženskom reprodukcijom. Treće, tijela su objekti moći i mjesta društvene inskripcije pa tjelesne politike u kojima se ogledaju politički i društveni odnosi uvijek nastaju s obzirom na neku hijerarhijsku formu. Grosz smatra kako treba pokazati kako je tijelo psihički, društveno, spolno i reprezentacijski proizvedeno (ibid., str. 104) jer se u njega upisuju različita kodirana značenja, disciplinarne prakse itd., kako bi postalo i ostalo dio društvene mreže.

Osim ovakvog viđenja u postfeminističkoj se teoriji javlja još niz različitih kritičkih analiza ove problematike od kojih ćemo izdvojiti sljedeće dvije. Prva od njih, nadovezujući se na stavove feministica drugoga vala, gleda na taj problem sukladno trendovima proizašlima iz ekološkog pokreta veličajući pritom prirodno i ne-modificirano tijelo (npr. Wolf, 2008.) dok druga ima izrazito pozitivan stav prema estetskim (nekirurškim i kirurškim) intervencijama u tijelo ${ }^{13}$. Dok je prvima uzor "prirodna" ljepota i "zdravo" tijelo, druga se struja zalaže za slobodan izbor u odabiru onih tehnoloških dostignuća koja će žene učiniti subjektima, odnosno

12 Odbacujući esencijalizam Grosz smatra kako žene nisu ontološki različite od muškaraca te da dominantno određenje ženskog spolnog identiteta proizlazi iz društvenih normi.

13 Ovo se, dakako, nikako ne smije miješati sa nekim, povremeno i voljnim, intervencijama u žensko tijelo, poput npr. podvezivanja stopala Kineskinja koje postfeministkinje jednoglasno određuju jednom od represivnih tradicionalnih praksi ništenja tijela u patrijarhalnim društvima. Zanimljiv je paradoks da će s druge strane mnoge feministkinje veličati ženske štikle ili visoke pete iako su učinci na žensko njihovo zdravlje i mobilnost vrlo slični. 
nositeljima slobodne volje u upravljanju vlastitim tijelom. Uz pozitivan stav prema tjelesnim modifikacijama neke postfeministkinje ističu važnost pornografije i ženskog istraživanja vlastite seksualnosti, smatrajući kako se njima, između ostalog, potiče subverzija patrijarhalnog poretka. Taj pristup ovim praksama umnogome je povezan s konstrukcijom ženskog identiteta te s istraživanjem efekata tih praksi na patrijarhalnu dominaciju.

Jesu li te prakse subverzivnog karaktera ili ne ostaje problematično. Ključnim se određuje pitanje jesu li one dovoljno snažne kako bi se pomoću njih žene oduprle tlačenju "anonimnog patrijarhalnog" te stekle status subjekta (Fraisse, 2006.:81). U odgovoru na to pitanje neki su odgovori optimistični, dok neki tvrde kako dominantne patrijarhalne prakse ne dozvoljavaju ženama mogućnost izbora i slobode (Sawicki, 1986.).

Ovoj, mogućnosno-subjektnoj poziciji posvetit ćemo nešto više pažnje kroz kontroverzni rad francuske umjetnice Orlan (2010.), najpoznatije po seriji radova iz 1990-ih godina u kojima je snimala vlastite, uglavnom facijalne estetske operacije koje su potom prikazivane diljem raznih umjetničkih institucija. Rad ove umjetnice analizirat ćemo iz dva razloga; kao ekstremni primjer interveniranja u tijelo ali i kao ženu/umjetnicu koja je kooptirala feminističke vrijednosti u svoj aktivističko/ umjetnički angažman pomoću kojeg progovara o nizu problema iz kritičke perspektive.

U provokativnoj seriji snimljenih kirurških izvedbi pod nazivom Ultimativno remek-djelo: Reinkarnacija Svete Orlan, ona iznosi svoj progresivni feministički stav na tragu antiesencijalističke i postfeminističke struje mišljenja. Svojim se umjetničkim radom odupire binarizmima tradicionalne zapadnjačke misli, prvenstveno onima između muškarca kao subjekta, umjetnika, aktivnog stvaraoca i žene kao pasivne materije, objekta podložnog muškim oblikovanjima i transformacijama. Orlan, preuzevši aktivnu, stvaralačku ulogu ništi taj binarizam kojim se ne samo određuje esencijalna različitost muškarca i žene već i jasna uspostava hijerarhije među njima.

Njezine ideje otvaraju mnoga pitanja, od kojih su neka dotaknuta i u ovom radu, a vezana su uz identitet, društvene tabue koji se suprotstavljaju kirurškom otvaranju tijela, dualizam um/tijelo, problematičnost odnosa između žena i tehnike/ tehnologije, granice umjetnosti i jezika, bol, reprezentaciju ženske groteske, mitove ženskosti, privatne i javne domene te dugo naslijeđe kolonizacije koju zapadnjačka medicina provodi nad ženskim tijelom (Hirschhorn, 1996.).

Prisvajanjem aktivne uloge stvarateljice svoga izgleda i oblikovateljice vlastita tijela Orlan je učinila tri bitna koraka: 1) izvršila je kritiku tradicionalnog poimanja umjetnosti prema kojem se žena u umjetnosti pojavljuje tek kao objekt lišen odjeće; 2) pružila je dalekosežniju kritiku koja prelazi umjetničke okvire osvrnuvši se na problem društveno nametnutih standarda ženske ljepote koji su se kroz povijest, između ostaloga, zrcalili u djelima muških umjetnika, a danas se ponovno 
reinkarniraju pod nožem estetskih kirurga i u vizijama modnih kreatora (i jednih i drugih muškaraca); 3) ponudila je svoje osobno rješenje kao umjetnica i kao žena, u vidu otpora nametnutim standardima.

U estetskim je operacijama Orlan našla način ne kako vratiti ljepotu u umjetnost, već kako industrijskim, komercijalnim i korporacijskim kapitalističkim interesima oduzeti pravo određivanja ljepote i njezinih kriterija. Ona želi biti lijepa no pritom želi da njezina ljepota bude proizvod njezine slobodne volje, umjetničkog nadahnuća i angažmana. Orlan, naime, ni u jednom trenutku nije pokušala dosegnuti ideal iako su, paradoksalno, ženski modeli ${ }^{14}$ prema kojima je modificirala svoje lice u jednom povijesnom trenutku odista važili kao ideali lijepog, čime je pokazala neizmjernu relativnost društveno proklamirane tjelesne ljepote.

Također, skrenula je pažnju publike na nekoliko važnih suvremenih problema vezanih uz estetsku kirurgiju od kojih su neki zanemarivanje boli i opasnosti mnogih neželjenih posljedica estetskih zahvata. Naime, estetska je kirurgija uvijek "sporna zona" budući da služi kao tampon između slobode i volje za preuzimanjem kontrole nad vlastitim životom s jedne strane i snage medicinskog autoriteta, koji se još uvijek služi ograničenim tehničkim mogućnostima, s druge. Unatoč neizmjernom razvoju kirurških tehnika, kemijskih sredstava i implantata te medijskoj slici mahom muških kirurga kao ljudi božanskih sposobnosti, estetska medicinska industrija na svoje proizvode stavlja visoku cijenu. Pacijenti često postaju objekti testiranja još nepoznatih kemijskih supstanci i tehničkih zahvata a loši rezultati ne dobivaju dovoljnu društvenu pažnju. Problem se prečesto svodi na pitanje taštine žena iz srednjih i viših društvenih slojeva.

Drugi važan problem otvoren je u kontekstu odnosa društva prema ljepoti, mladosti i zdravlju. Naime, ako je ljepota stvar zdravlja ali i obaveze i odgovornosti prema svome tijelu kako je moguće da ju se nastoji postići i održati opasnim, invazivnim i riskantnim metodama koje pritom ugrožavaju zdravlje? Da se radi o svojevrsnom paradoksu svjedoči i društveno licemjerje koje s jedne strane uzdiže "plastične ljepotice" a s druge strane, prilikom promatranja estetskih postupaka kojima se ta ljepota gradi, iskazuje otpor, gađenje i šok.

Sljedeći moment Orlanine kritike povezan je uz otpor hegemoniji svih standarda pa tako i onih o ljepoti. Ljepota je kao pojam djelomično napustila suvremenu umjetnost ali je zato obilato prihvaćena u kapitalističkoj ideologiji. U srži je umjetnosti originalnost, pa su standardi više primjereni logici industrijske proizvodnje koja kreira unisone proizvode čije se mijene primjećuju tek kroz povremena usavršavanja, prvenstveno u cilju bolje prodaje. Kritizirajući standarde, Orlan naglašava važnost individualnosti i kreativnosti u stvaranju onoga što želi biti. U odbijanju konformizma ona vidi mogućnost izgradnje ženskog identiteta koji neće biti fiksi-

14 Naime, Orlan se kao uzorima poslužila Botticellijevom Venerom, Psihom Jean-Léon Gérômea, Europom François Bouchera i da Vincijevom Mona Lisom. 
ran već, na tragu postmodernističkih teorija, u konstantnoj mijeni, protoku, preoblikovanju i potrazi. Time, na tragu stavova Donne Haraway (1999.) pronalazi u tehničkim sredstvima emancipacijske mogućnosti kojima se žene mogu poslužiti i na taj način izbjeći stigmu vječne inkorporiranosti u prirodno.

Iako Orlan u svojim estetskim zahvatima ističe snagu oslobođenja ženskog tijela i izgradnju identiteta po svojoj volji, ipak valja ukazati na nekoliko ključnih problema vezanih uz Orlanin i postfeministički odnos prema tjelesnim modifikacijama. Osnovni problem koji se zrcali kroz rad Orlan, vezan je uz dualizam i razdvajanje tijela od svijesti o sebi. Svoje operativne performanse, Orlan započinje čitanjem jednog te istog teksta lakanovske psihoanalitičarke Eugenie Lemoine-Luccioni u kojem ova sugerira šizmu između onoga što jesmo i onoga što imamo. To u Orlaninom umjetničkom djelovanju predstavlja razdvajanje i sukob između onoga što ona jest, tj. onoga što ona misli da jest, i tijela kojeg ima. Ta granica koja se simbolički i stvarno označava kožom prevladava se estetskom kirurgijom i ostalim tjelesnim modifikacijama koje njoj i mnogim ženama pomažu ostvariti harmoniju između stanja duha i tjelesne slike. Taj je problem zaživio u popularnoj kulturi i modernim ženskim stavovima o vlastitom tijelu izraženih izjavama: "Ja nisam ovo tijelo" ili "u ovom se pretilom tijelu skriva jedna mršava osoba". Ovi naizgled jasni stavovi kriju u sebi određene nepreciznosti i nejasnoće. Prvo, kakvi to jesmo ako vlastito tijelo predstavljamo kao nešto toliko strano pa čak i neprijateljsko? Tko smo mi ako nismo to tijelo i na osnovu čega smo tako snažno uvjereni da to i takvo tijelo koje imamo nije ono "pravo" tijelo?

Za Orlan je cilj kirurškog performansa bila sloboda izbora no je li to tako za sve pacijente koji leže u ordinacijama estetskih kirurga? Kirurzi većinom stvaraju "kopije" a ne originale te smatraju svojom odgovornošću odvratiti pacijenta od eventualnih suviše "ekscentričnih ideja" vezanih uz njegov/njezin budući izgled. Čak niti Orlan nije mogla ostvariti sve svoje želje vezane uz promjenu svoga lica; iako nije bilo nikakvih tehničkih prepreka imala je mnogo poteškoća prilikom pronalaska kirurga koji će izvršiti željene zahvate. Tek je kirurginja, feminističke orijentacije, pristala na ugradnju rožnatih implantata u Orlanino čelo.

Dakako, mogli bismo reći kako se ipak radi o svojevrsnom oslobođenju, oslobođenju od biološke zadanosti koje se zasniva na odabiru pa onda i kupovini poželjnog tjelesnog izgleda. Pitanje je koliko ti individualni činovi slobode (p) održavaju slobodu čovjeka, napose žene, u cjelini a koliko ju nište (p)održavajući postojeće matrice društvene represije. Je li moguće postići slobodu oblikovanjem tijela uz pristajanje na niz ovisnosti - od one materijalne pa do operativnih, budući da kompleksniji operativni zahvati najčešće idu u nizu, jedan za drugim, prividno ispravljajući greške ili nesavršenosti onih potonjih? Je li odista sloboda "zdravo tijelo" pretvoriti u "bolesno" jer pristajanjem na kirurške intervencije individua postaje svjesni pacijent cijeli svoj život?

S druge strane, ako je to odista čin emancipacije koliko je on dostupan svima? Je li time ženska emancipacija i dalje stvar mahom bogatih, privilegiranih, bijelih že- 
na? Da li mediji reklamirajući te zahvate posredno čine "dobru stvar" nagovarajući na emancipaciju i one manje bogate, ne-bijele žene, s obzirom da cijene estetskih operacija postaju sve jeftinije i pristupačnije?

Iako pružaju neke odgovore, rješenja postmodernog feminizma ukazuju i na kontroverze jer koncentrirajući se na tjelesnost i individuu, ponekad zaboravljaju na šire, društveno objašnjenje te pokazuju nedostatak sluha za stare podjele i društvene nejednakosti.

Postmoderne feminističke teorije tijela stavljaju prvenstveno naglasak na jastvo i njegov pokrov (tijelo) bez da propituju utjecaj društvenoga i temeljnu činjenicu kako stav o sebi i vlastitom tijelu stvaramo u odnosu na druge. I time dolazimo do problema koji više nema (samo) rodne odrednice - uvjerenja kako jastvo ne odgovara slici tijela. Naime, i žene i muškarci sve se više suočavaju s problemom neprilagodbe vlastitome tijelu; oni se nalaze u rascjepu između onoga kakvima se osjećaju i kakvima bi zapravo željeli biti, nesvjesni da su tim osjećajem ulovljeni u zamku sistema koji upiranjem prsta u ljudske mane i nedostatnosti uvećava osjećaj nezadovoljstva i očaja te stvara masu poslušnih konzumenata, gladnih i vježbom opsjednutih gutača dijetetskih napitaka, korisnika kozmetike i operativnih zahvata.

Ono što nam možda ostavlja nadu u potencijal estetskih operativnih postupaka jest njihovo omasovljenje (koliko god ta pojava u suštini bila problematična) te prijelaz iz sfere skupe nužnosti medijskih radnika i bogatih ili potencijalno bogatih karijerista u sferu slobode, igre i zabave. To bi trebalo biti dodatno omogućeno razvojem medicinskih tehnika te vjerojatnim povećanjem sigurnosti kirurških postupaka. Nadamo se da to u sebi sadrži potencijal prema budućem otvorenijem, strasnijem i kreativnijem odnosu prema vlastitom tijelu te prema pokušajima otpora društveno nametnutim idealima i njihovim standardima.

\section{Zaključak}

Rana su filozofska i teološka razmišljanja udarila temelje diskursu o tijelu kao tamnici duha, mračnoj pećini nagona i strasti. Binarizmi i hijerarhizmi koji su bili osnovna karakteristika tradicionalnog mišljenja o tjelesnosti, tijelo su smjestili nasuprot uma dajući mu, u toj hijerarhiji, niže značenje. Inovativniji teorijski pristupi, zainteresirani za tu problematiku, pokušali su (re)definirati pojam tijela - od pukog receptora kulturnih efekata i odnosa moći - do jedne od najvažnijih odrednica identiteta.

Novije spoznaje, dakle, tvrde kako je tijelo primatelj društvenih praksa ali i oruđe bivanja, osjećanja i kreiranja svijeta. Ipak, odnos društva i tijela tek treba biti istražen. Budući da su mnoge nove spoznaje proglasile tjelesno iskustvo temeljem ljudske egzistencije i odnosa s okolinom uviđa se važnost istraživanja odnosa društva i tijela. Na taj način shvaćeno tijelo postaje dijelom "impresijskog menadžmenta", kapital u koji vrijedi ulagati ali i potencijalno mjesto istinske ljudske kreacije. 
U postmodernitetu svi su aspekti tjelesnosti teoretski otvoreni prema mogućnostima mijenjanja pri čemu tehnologija omogućava lakšu i bržu aplikaciju promjena, što, međutim, ima svoje dvojbene estetske i zdravstvene konzekvence.

Analizirati tijelo u modernim društvima danas, po logici stvari, mora uključiti svijest o postojanju i utjecaju konzumerističke kulture kao i globalizacijskih procesa koji imaju utjecaj na razloge i načine prakticiranja kirurških tjelesnih modifikacija. Taj smo odnos ovdje pokušali rasvijetliti u kontekstu kulturnog imperijalizma, odnosno prihvaćanja zapadnih tjelesnih standarda ("standardizacija" i "vesternizacija" tijela) te u kontekstu kooptiranja multikulturnih utjecaja u tjelesne modifikacije.

U tako sazdanom okviru, tijelo i tjelesni kapaciteti postaju nepresušan izvor zarade, a komercijalni interes za njega stalno raste. Ako je tijelo postalo kreativnim sredstvom komunikacije i profesionalne mobilnosti te ako u konzumerističkom društvu za funkcionalnim i lijepim tijelom postoji neprestana potražnja onda se isplati igrati i investirati u njega. Pritom se nikako ne smije zanemariti činjenica kako je tijelo nositelj oznaka moći. Ono je povezano s radnim procesom, socijalnom mobilnošću te je podložno instrumentalizaciji.

Instrumentalizirajući ali i potencijalno kreativni pristupi tijelu evidentirani su na primjerima grotesknih tijela kojima smo odredili namjerno izobličena tijela iz vjerojatno umjetničkih i/ili komercijalnih ili nekih drugih razloga. "Društvenost tijela" pokušali smo pokazati kroz procese distanciranja od dobi, obiteljskog fizičkog naslijeđa kao i etničko/rasnog. Vjerujemo da je lepeza distanciranja mnogo šira i da ima mnoge reperkusije koje bi još trebalo istražiti.

Pokazali smo kako u analizi tijela spol/rod igra ključnu ulogu. Pritom smo veću pažnju posvetili ženskim tijelima kao onima koja ne možemo promatrati izvan patrijarhalne rodne matrice. Patrijarhalna rodna matrica, naime, počiva na cirkulirajućim stereotipnim idejama o ženskom tijelu i njegovoj pasivnosti i nemoćnosti. Koliko se tijelo kao osobni projekt u okviru takvih vrijednosti može oduprijeti upisivanju patrijarhalnog društva u žensku tjelesnost?

U pokušaju odgovora na ovo pitanje, može se reći kako su žene danas premoćne konzumentice postupaka tjelesnih modifikacija što pokazuje kako je tijelo i nadalje premoćna sastavnica ženskog identiteta. Začarani krug potrošnje ne obuzima samo žene viših društvenih slojeva nego polako svojom cijenom postaje dostupan i ženama iz nižih društvenih slojeva i sve se one trude tijelom (do)stići ljepotu i standarde medijsko proklamiranih tjelesnih ideala. Osim toga, kultura vrši pritisak na tijela oba spola/roda u smjeru brige za tijelo (dijetni i fitnes režimi, kozmetička uljepšavanja i operativni zahvati).

Baveći se tijelom iz ugla postfeminističke teorije ukazali smo na nekoliko razina toga problema. Bitnom valja odrediti jednu od postfeminističkih ideja prema kojoj individualni činovi transformacije tijela mogu biti subverzivnog karaktera u odnosu na patrijarhalnu zadatost. Tehnologija se u tom kontekstu pojavila kao 
kontroverzni "prijatelj" ženskoga tijela čijom se transformacijom vrši kritika poretka na nekoliko razina što je zorno iz umjetničkog rada francuske umjetnice Orlan. Orlanin je rad pokazao umjetničko utiranje puta prema kritici i kreaciji koristeći elemente vizualno šokantnog i zazornog prkoseći unifikaciji tijela prema diktatu dominantnih vrijednosti.

Ipak, postfeminističko viđenje tjelesnih modifikacija ne vodi u dovoljnoj mjeri računa o onome što Schilling s punim pravom uvodi u analizu tijela, a to je analitika brojnih varijabli, koje uključuju vrijeme te različite društvene kontekste u kojima ta tijela djeluju.

S obzirom na perspektivu možemo reći kako će tehnologijom posredovana tijela postajati sve češće mjesta ljudskih potreba, navika i kreativnosti a kakve će to imati daljnje reperkusije na društvo treba vidjeti u budućim istraživanjima.

\section{Literatura}

1. Anić, V. et al. (2004). Hrvatski enciklopedijski rječnik. Zagreb: Novi liber.

2. Atiyeh, B. S.; Kadry, M.; Hayek, S. N.; Musharafieh, R. S. (2008). Aesthetic Surgery and Religion: Islamic Law Perspective. Aesthetic Plastic Surgery, 32:1-10.

3. Bakhtin, M. (1984). Rabelais and His World. Bloomington; Indianapolis: Indiana University Press.

4. Bartky, L. S. (2006). Foucault, ženskost in modernizacija patriarhalne oblasti. Delta, 12(1-2):59-96.

5. Baudrillard, J. (1998). The Consumer Society: Myths and Structures. London: Sage.

6. Baudrillard, J. (2001). Simulacija i zbilja. Zagreb: Naklada Jesenski i Turk, Hrvatsko sociološko društvo.

7. Bauman, Z. (2000). Liquid Modernity. Cambridge: Polity.

10. Beavouir de, S. (1982). Drugi pol. Beograd: Beogradski izdavački-grafički zavod. 2 sv.

11. Beck, U. (1992). Risk Society: Towards a New Modernity. Cambridge: Sage.

12. Bourdieu, P. (1978). 'Sport and social class'. Social Science Information, 17(6):819-840.

13. Bourdieu, P. (2001). Vladavina muškaraca. Podgorica: CID.

14. Butler, Judith (2000). Nevolje s rodom: feminizam i subverzija identiteta. Zagreb: Ženska infoteka.

15. Davis, K. (2002). 'A Dubious Equality': Men, Women and Cosmetic Surgery. Body and Society, 8 (1):49-65.

16. Deleuze, G. i Guattari, F. (2004). A Thousand Plateaus: Capitalism and Schizophrenia. New York: Continuum.

17. Durkheim, E. (2008). Elementarni oblici religijskog života: totemistički sustav u Australiji. Zagreb: Naklada Jesenski i Turk, Hrvatsko sociološko društvo.

18. Featherstone, M. (1999). Body Modification: An Introduction. Body sSociety, 5:1-13.

19. Foucault, M. (1978-1988). Istorija seksualnosti. Beograd: Prosveta. 3 sv.

20. Foucault, M. (1990). Predavanja: (kratak sadržaj): 1970-1982/ Mišel Fuko. Novi Sad: Bratstvo - Jedinstvo.

21. Foucault, M. (1994). Nadzor i kazna: rađanje zatvora. Zagreb: Informator: Fakultet političkih znanosti. 
22. Friedman, M. D. (2005). Glava za sebe: Kulturna povijest penisa. Zagreb: Jesenski i Turk.

23. Giddens, A. (1991). Modernity and Self-Identity. Self and Society in the Late Modern Age. Stanford: Stanford University Press.

24. Giddens, A. (2000). Preobrazba prisnosti : spolnost, ljubav i erotika u modernim društvima. Split: Laus.

25. Giddens, A. (2005). Odbjegli svijet: kako globalizacija oblikuje naše živote. Zagreb: Naklada Jesenski i Turk.

26. Giddens, A. (2007). Sociologija. Zagreb: Nakladni zavod Globus.

27. Gilman, S., Sander L. (2001). Making the Body Beautiful. New Jersey: Princeton University Press.

28. Goffman, E. (1956). Presentation of Self in Everyday Life. Edinburgh: University of Edinburgh, Social Science Research Center.

29. Goffman, E. (1976). Gender Advertisements. New York: Harper and Row Publishers Inc.

30. Green, A. (2008). The Social Organization of Desire: The Sexual Fields Approach, Sociological Theory, 26(1):25-50.

31. Grosz, E. (1995). Space, Time and Perversión: Essays on the Politics of Bodies. NewYork: Routledge.

32. Harcet, M. (2010). Kada dolaze na red ljudska, posebno ženska prava?, u: Kodrnja J.; Savić S. i Slapšak Svetlana (Ur.). Kultura, Drugi, žene. Zagreb: Plejada; IDIZ; HFD.

33. Haraway, D. (1999). Manifesto za kiborge, u: Nicholson J. Linda (Ur.). Feminizam / postmodernizam. Zagreb: Liberata: Ženski studiji.

34. Hilhorst, T. M. (2002). Scientific Contribution Physical beuty: Only skin deep? Medicine, Health Care and Philosophy, 5:11-21.

35. Hirschhorn, M. (1996). Orlan: Artist in the Post-human Age of Mechanical Reincarnation, u: Pollock, Griselda (Ur.). Generations and Geographies In the Visual Arts - Feminist Reading. New-York: Routledge.

36. Holliday, R. i Sanchez Taylor, J. (2006). Aesthetic surgery as false beuty. Feminist theo$r y, 7: 179-195$.

37. Ishiguro, J. (2009). Westernized Body or Japanized Western Body: The Desirable Female Body in Contemporary Japanese Women's Magazines, u: Turner, Bryan, Yangwen, Zheng (Ur.). The Body in Asia. Oxford: Berghahn books.

38. Jung, J. (2006). Media Influence: Pre- and Postexposure of College Women to Media Images and the Effect of Mood and Body Image. Clothing and Textiles Research Journal, 24:335-344.

39. Jung, J. i Forbes, G. (2007). Body Dissatisfaction and Disordered Eating among College Women in China, South Korea, and the United States: Contrasting Predictions from Sociocultural and Feminist Theories. Psychology of Women Quarterly, 31(4):381-393.

40. Kaspersen, L. B. (2000). Anthony Giddens. An Introduction to a Social Teorist. Oxford: Blackwell Publishers Inc.

41. Lončarek, K. (2009). Asymptotic medicine. Croatian Medical Journal, 50(1):83-86.

42. MacNair, B. (2004). Striptiz kultura: seks, mediji i demokratizacija žudnje. Zagreb: Jesenski i Turk.

43. Kalanj, R. (2004). Globalizacija i postmodernost. Zagreb: Politička kultura.

44. Marot Kiš, D. i Bujan, I. (2008). Tijelo, identitet i diskurs ideologije. Fluminensia, 20 (2):109-123

45. Marx, K. (1958). Kapital. Kritika političke ekonomije. Prvi tom. Beograd: Kultura.

46. Mumford, D. i Choudry, I. (2000). Body Dissatisfaction and Eating Attitudes in Slimming and Fitness Gyms in London and Lahore: A Cross-Cultural Study, European Eating Disorders Review, 8(3):217-224. 
47. Oraić Tolić, D. (2001). Muška moderna i ženska postmoderna. Kolo, 2:220-232.

48. Paić, Ž. (2005). Politika identiteta: Kultura kao nova ideologija. Zagreb: Antibarbarus.

49. Park, S. Y. (2005). The Influence of Presumed Media Influence on Women's Desire to Be Thin. Communication Research, 32:594-614.

50. Pateman, C. (2000). Spolni ugovor. Zagreb: Ženska infoteka.

51. Pitts, V. (2003). In the flesh. The cultural politics of body modification. New-York: Palgrave MacMillan.

52. Quah, Danny (2003). The Weightless Economy. Pregledano: 3. srpnja 2010. (http:// econ.lse.ac.uk/čdquah/tweirlo.html).

53. Sawicki, J. (1986). Foucault and Feminism: Toward a Politics of Difference. Hypatia, 1(2):23-36.

54. Schilling, C. (2005). The Body in Culture, Technology and Society. London: Thousand Oaks; New Delhi: Sage Publications.

55. Simmel, G. (2001). Kontrapunkti kulture. Zagreb: Naklada Jesenski i Turk, Hrvatsko sociološko društvo.

56. Smith, R. (2002). In search of "non-disease". British Medical Journal, 324:883-885. Pregledano: 10. kolovoza 2010. (http://www.bmj.com/cgi/reprint/324/7342/883).

57. Varga, I. (2005). The Body - The New Sacred? The Body in Hypermodernity. Current Sociology, 53(2):209-235.

58. Višnjić, J. i Mirosavljević, M. (2008). Problem reprezentacije roda u medijima, u: Zaharijević Adrijana (Ur.). Neko je rekao feminizam. Beograd: Žene u crnom; Centar za ženske studije; Rekonstrukcije Ženskog fonda.

59. Young, I. M. (2005a). Pravednost i politika razlike. Zagreb: Naklada Jesenski i Turk.

60. Young, I. M. (2005b). On Female Body Experience: "Throwing Like a Girl" and Other Essays. Oxford. New York: Oxford University Press.

61. Wolf, N. (2008). Mit o ljepoti. Zagreb: Naklada Jesenski i Turk.

Internetski izvori:

U tekstu: Američko društvo za estetsku kirurgiju (2010.)

Pregledano: 17. kolovoza 2010.

(http://www.cosmeticplasticsurgerystatistics.com/statistics.html).

U tekstu: Orlan (2010.)

Pregledano: 20. srpnja 2010.

(http://www.orlan.net/).

Pregledano: 24. srpnja 2010.

(http://www.youtube.com/watch?v=IQ1Ph-Pprj4). 


\title{
Mirjana Adamović
}

Institute for Social Research - Zagreb

e-mail:mirjana@idi.hr

\section{Ana Maskalan}

Institute for Social Research - Zagreb

e-mail: ana@idi.hr

\section{Body, Identity and Body Modifications}

\begin{abstract}
The article deals with the relationship between body and identity, considering the impact of structural factors (globalization, capitalism) on positioning of the body in modern societies. It starts from the assumption that global markets are encouraging standardization of consumer habits and values that manifests itself in the modes of body modification. The emphasis is put on invasive modifications (cosmetic surgery) which influence the age-group, family and racial/ethnic identification. The trends of changing the physical appearance are guided by the looks of body ideals that have, through products of cultural industries, a global impact. Thus are present, beside the "westernization" of body appearance, other non-homogenic forms of "standardization" as well as the procedures of the deliberate body "grotesquization".

In this paper it is shown that modifications are supporting wider inequalities and cannot be viewed outside the gender power matrix. Since this problem is a frequent subject of (post) feminist theories we have used these views to analyze and problematize extreme body modifications immanent in the subversive works of the French artist Orlan which alter the patriarchal expectations towards women.
\end{abstract}

Key words: body, identity, globalization, women, body modifications, consumerism, cosmetic surgery. 